\title{
'Inherited commitments': do changes in ownership affect corporate social responsibility (CSR) at African gold mines?
}

Article

Published Version

Hilson, G. (2011) 'Inherited commitments': do changes in ownership affect corporate social responsibility (CSR) at African gold mines? African Journal of Business Management, 5 (27). pp. 10921-10939. ISSN 1993-8233 doi: https://doi.org/10.5897/AJBM10.1608 Available at https://centaur.reading.ac.uk/24915/

It is advisable to refer to the publisher's version if you intend to cite from the work. See Guidance on citing.

To link to this article DOI: http://dx.doi.org/10.5897/AJBM10.1608

Publisher: Academic Journals

All outputs in CentAUR are protected by Intellectual Property Rights law, including copyright law. Copyright and IPR is retained by the creators or other copyright holders. Terms and conditions for use of this material are defined in the End User Agreement. 


\section{CentAUR}

Central Archive at the University of Reading

Reading's research outputs online 


\title{
'Inherited commitments': Do changes in ownership affect corporate social responsibility (CSR) at African gold mines?
}

\author{
Gavin Hilson \\ School of Agriculture, Policy and Development, The University of Reading, Earley Gate, P.O. Box 237, Reading RG6 \\ 6AR, UK . E-mail: g.m.hilson@reading.ac.uk. \\ Accepted 14 April, 2011

\begin{abstract}
This paper critically examines the issue of 'inherited corporate social responsibility' in the gold mining industry, focusing specifically on the case of sub-Saharan Africa, a region plagued with excessive corruption, rampant poverty and weak governance. Whilst there appears to be little incentive to proactively engage with communities and implement cutting-edge environmental policies in the region, mine managers argue otherwise, highlighting a number of reasons for embracing corporate social responsibility (CSR). After briefly reviewing the philosophical underpinnings of CSR, the paper provides an in-depth analysis of these arguments, in the process, underscoring how tenuous the case for CSR in the extractive industries, and gold mining more specifically, is in the context of sub-Saharan Africa. Following a change in ownership, new management faces few pressures to embrace CSR in its entirety and therefore, more often than not, finds itself in a position to implement programs and policies of its choice. More research is needed that further popularizes the issue of 'inherited CSR' in the gold mining sector and extractive industries more generally.
\end{abstract}

Key words: Inherited, corporate social responsibility (CSR), gold mining, social license to operate, Ghana.

\section{INTRODUCTION}

The aim of this paper is to bring to light the issue of 'inherited corporate social responsibility' at gold mines. Over the past two decades, corporate social responsibility (CSR) has been heavily popularized in the gold mining industry, its managers and CEOs arguing that firm commitments to stewardship and environmental protection are keys to maximizing the profitability of projects. In addition to proponents contesting that there is a business case for CSR in the sector, it is often argued that gold mining companies must secure a 'social license to operate'; and, because they can be held accountable by catchment communities, regulators and NGOs, that companies have strong incentive to embrace CSR to its fullest.

But what happens when a company takes over a gold mine whose management has made firm commitments to community development and environmental protection? This phenomenon - referred to here as 'inherited CSR' has received very little attention in the literature, let alone in the context of gold mining, an industry in which changes in ownership occur frequently. In recent years, criticisms of gold mining companies' environmental and social performance have mounted (EARTHWORKS, 2003; Lange, 2006; Pegg, 2003, 2006) but few analyses have taken stock of the industry's dynamic managerial structure and the impacts a change in mine ownership can have on CSR. This applies to sub-Saharan Africa, a region where corruption is rampant, fiscal transparency is low and, despite what may be said otherwise, the pressure to embrace the concerns of communities is virtually nonexistent. Much in the way that extant contracts with workers tend not to be honoured, suppliers are changed and production facilities are closed following the arrival of new management at a gold mine, commitments to community and CSR programs can also be sidelined.

In order to appreciate what impact a change in ownership may have on local people, it is imperative to first revisit the arguments on which the case for CSR in the extractive industries - and the gold mining 
sector more specifically - has been built. As will be explained although mining companies have been at the forefront of the debate on CSR, its CEOs championing its importance in 'accessing' economic deposits and preserving shareholder value, there is little evidence to support the general arguments on which the industry's case is based. These arguments are most tenuous in the case of sub-Saharan Africa, where again, governance and accountability is lacking: there appears to be very little incentive to engage in CSR at gold mines in developing countries overall, and very little proof that doing so provides any financial advantage.

The paper focuses on the issue of 'inherited' commitment itself. First, it reviews some of the recent major changes in ownership that have taken place in the gold mining industry which have potentially had a bearing on CSR outcomes at projects in sub-Saharan Africa. The paper then draws upon experiences from Ghana to illustrate how easily commitments to the environment and communities can be sidelined, even in situations where there is a legacy of CSR. The case of Ghana reveals that, in a business climate devoid of pressures to perform responsibly, there is no single 'best' CSR strategy. Rather, gold mining companies are at liberty to decide which path to follow because as is shown, markedly different approaches can yield equally positive financial outcomes. The ability of companies to implement radically different programs to those which they 'inherit' discredits further the anecdotal arguments on which the case for CSR in the gold mining industry has been built.

\section{CORPORATE SOCIAL RESPONSIBILITY (CSR): A CRITICAL OVERVIEW}

Critical analyses of 'corporate social responsibility' first surfaced in the academic literature in the 1970s, in what is widely regarded as the 'environmental decade'. A global conservation movement that had galvanized towards the late-1960s would trigger a mass overhaul of environmental legislation, initially in North America, and subsequently, in Europe (Dunlap and Mertig, 1991). The changes exposed many companies' polluting practices; magnified how little industry was doing to prevent contamination of environmental media; and even revealed the extent to which some corporations were contributing to environmental problems, most notably, acid rain and ozone depletion. To ensure compliance with newly-implemented environmental legislation and avoid costly fines, companies were forced to spend tens of millions of dollars to replace polluting production processes and install new technologies. The sweeping changes made to laws mobilized unions and the media, which began pressuring companies to become 'more responsible citizens' within the localities where they operated.

This was indeed a period of transition for multinational corporations, which had hitherto grown accustomed to operating with minimal regulatory pressure. For most, the idea of being responsible stewards seemed alien, contradicting the very modus operandi of doing business. As explained by Ostlund (1977) at the time, 'in reaction to pressures on all fronts, corporations are being called upon to direct attention and resources to social problems far removed from their central economic mission... demands (which) are vague, even though forceful, and conflicting even though worthy'. Bowman and Haire (1975) elaborated further on what management clearly perceived to be a huge challenge and potentially, an impediment:

'It has become an increasingly perplexing problem for corporate strategists to find an appropriate posture for what may be called corporate citizenship or social responsibility. Among the things that make it difficult are two prevalent myths: the activities in this area are in fundamental conflict with the interests of the investor, and that resources committed to such activities come, net, out of the equity holder's pocket; and that the motivation for such activities lies only in a sense of noblesse oblige on the part of the group formulating the strategy, and again, is an interest not directly related to the equity holder's welfare'.

As discussions on 'corporate stewardship', 'pollution prevention' and 'corporate responsibility' intensified, the social and environmental performance of companies, particularly those which struggled to meet newlyimplemented standards and/or openly resisted the growing demands of communities, began to attract media spotlight. Confusion over how to cope with growing societal expectations permeated all levels of operation. A wave of studies on CSR undertaken in the 1970s (Carroll 1974, 1978; Holmes, 1976; Shanklin, 1976) captured this, underscoring the difficulties executives were having with industry assuming a stewardship role.

Yet, what seemed unfathomable four decades ago has since become a reality. Today, CSR is the focal point of most multinationals' core business strategies, and is often the featured theme on their internet homepages. So called 'leading-edge' companies now have in place programs that address environmental and social issues fairly comprehensively. In fact, corporations have become so well equipped for managing mounting concerns about the environment and communities that some scholars (Chen et al., 2008; Gifford et al., 2010) have portrayed them as philanthropic and charitable entities; many have even labelled particular firms 'good stewards' and 'good citizens'. 'Strategic CSR', however, has become the preferred approach of businesses today simply because of the view that it yields 'substantial business-related benefits to the firm, in particular by supporting core business activities and thus contributing to the firm's effectiveness in accomplishing its mission [of profit 
Table 1. Selected mining sector reform project implemented in sub-Saharan Africa.

\begin{tabular}{llcc}
\hline Country & Project & $\begin{array}{c}\text { Year } \\
\text { Implemented }\end{array}$ & $\begin{array}{c}\text { Amount } \\
\text { (US\$) }\end{array}$ \\
\hline Burkina Faso & Mining Sector Capacity Building and Environmental Management project & 1997 & 21.4 \\
Ghana & Natural Resources and Environmental Governance First Development Policy & 2008 & 20 \\
& Operation & & \\
Mozambique & Mineral Resources Management Capacity Building Project & 2001 & 18 \\
Nigeria & Sustainable Management of Mineral Resources Project & 2004 & 120 \\
Uganda & Sustainable Management of Mineral Resources Project & 2003 & 25 \\
\hline
\end{tabular}

maximization]' (Burke and Logsdon, 1996). Few Industries have embraced CSR as comprehensively - at least on paper - as mining, which operates in some of the most ecologically and culturally-sensitive environments across the world. The largest mining companies have relied heavily on CSR dialogue to facilitate access to such places.

In order to become what Burke and Logsdon (1996) classify as 'more strategic', firms must first establish divisions capable of managing, relatively autonomously, environmental and interrelated social concerns. In the mining industry, this task has been, and continues to be, herculean: persuading sceptics to dismiss a series of socially and environmentally destructive incidents. Notable examples include civil conflict in Bougainville Papua New Guinea, sparked by community grievances over mining; the environmental destruction caused by the Australian company, BHP Billiton, at Ok Tedi in Papua New Guinea; and mounting complications with communities based around Newmont's Yanococha Mine in Peru. The challenge has been persuading the Indus-try's harshest critics and a sceptical public that environmental and social concerns are now being addressed far more comprehensively - that management is now fully committed to 'not only its shareholders, but also to other stakeholders, including employees, customers, affected communities and the general public, on issues such as human rights, employee welfare and climate change' (Jenkins and Yakovleva, 2006). Mining companies, therefore, have established departments to handle CSRrelated issues. Most are staffed with a range of experts, including anthropologists, economists, environmental specialists and engineers. These units have helped to mitigate against actions taken by NGOs, as well as lobbying indigenous groups, which, as Kapelus (2002) explains, have 'increased their organizational capacity and cooperation tremendously over the last twenty years or so'.

The establishment of departments capable of buffering against such resistance has also helped the mining sector expand into developing countries. In the 1990s, the World Bank began scaling up support for programs emphasizing mining-led growth in the developing world, particularly across sub-Saharan Africa. In its landmark report, A Strategy for African Mining (World Bank, 1992), a comprehensive blueprint for growth was outlined. It emphasizes a model of export-led development, calling on African leaders to overhaul national mining legislation to provide generous investment incentives for prospective mining and mineral exploration companies, privatize mine parastatals, and reduce government intervention in the sector. A wave of World Bank mining sector reform programs have since been implemented (Table 1). The changes these spawned proved instrumental in securing investment from international mining houses such as Barrick Gold, Newmont Gold Mining, Rio Tinto and Golden Star Resources, which now operate numerous projects across sub-Saharan Africa. The CSR departments of these, and other, major mine operators, have helped to deflect criticism from NGOs; their entry and/or expansion in the region has been facilitated in part by renewed commitments to community development and environmental protection.

Central to accomplishing this has been a crucial second change: namely a pledge to putting the 'community' at the heart of CSR dialogue, programs and policy. For decades, across the developed world, companies profited substantially from operating unsafe, lowcost polluting activities that provided catchment communities with few economic benefits. But increased awareness of these impacts in media circles and the general public, along with heighted regulatory pressure, has since made the establishment of regular dialogue with, and the awarding of compensation to, communities, virtually mandatory in Europe and North America: the literature on CSR is now 'permeated with references to how corporations perceive themselves to be part of the community' (Kapleus, 2002). For the mining industry, forging cordial relations with communities - or at least conveying the impression that community concerns are being addressed more proactively - is of paramount importance because activities are often established in areas populated by subsistence indigenous groups. As Jenkins and Yakvoleva (2006) explain, 'though traditionally seen as a potential impediment to development, with the globalization of opposition to mining developments and the emancipation of indigenous rights, engagement with aboriginal groups has become a 
reputational and political imperative for mining companies'. Firms operating in Australia, for example, have had little choice but to establish dialogue with the aborigines inhabiting remote areas containing coveted gold deposits (Young, 1992; O'Faircheallaigh, 2006). Companies operating in areas of Canada and the United States inhabited by First Nations groups have had to do the same (O'Faircheallaigh, 2010; Weitzner 2010).

A third strand of strategic CSR is proactive reporting. Over the past two decades, there has been growing emphasis placed by the management of multinationals on detailing industrial activities, highlighting actions undertaken to establish positive relations with communities, and disclosing details about corporate-sponsored community development activities. This information has been disseminated in CSR reports and on company web pages. It is often argued that through reporting, the management of multinationals demonstrate a high level of commitment to transparency and to informing wider audiences of the activities being undertaken to support affected communities.

Increased documentation of CSR activities in corporate media has spawned a literature on 'corporate citizenship'. Most of the earliest pieces on this topic contest that profit maximization and community development go hand-inhand. Many of the more recent discussions on 'corporate citizenship' (Warhurst, 2001), however, appear far removed from the reality that 'corporate social responsibility is not without limits' and how 'the manager cannot "give away the store"' (Byron, 1982). The impression conveyed by this relatively uncritical body of analysis is that the very corporations which, inter alia, once polluted rivers freely and contributed minimally to the very communities where they operated have morphed into philanthropic organizations. Such glorification and misrepresentation of CSR often deludes societal groups, many of which now also mistakenly view corporations as charities and therefore place unrealistic demands on their management.

This is a potential problem in the large-scale gold mining industry, which is expanding rapidly across the world, propelled by record high gold prices. The unprecedented growth in gold mining and exploration that has occurred over the past two decades in sub-Saharan Africa in particular - a region characterized by weak governance, high levels of corruption, and persistent and endemic poverty - is a concern, or at least should be. In implementing the formula prescribed for large-scale, export-driven mining growth in A Strategy for African Mining, many of the region's governments have established relatively easy routes of entry for hundreds of foreign gold mining and mineral exploration companies. But with few exceptions, catchment communities have derived few benefits from incoming activity (Pegg, 2006). This has led to the industry attracting even more unwanted criticism. To their credit, most have implemented community development programs that aim to service the localities where gold exploration and/or mining mining projects have been established. How effective have these moves been? More importantly, are the companies operating in sub-Saharan Africa genuinely committed to putting communities at the heart of corporate strategy? These issues require further investigation. Gold mining now flourishes in some of the region's most corrupt countries where, despite there being few incentives and pressures to embrace community concerns, international mining houses have indicated that they have launched social development programs.

Increased reportage by both CSR departments and NGOs on Africa's mining growth has failed to yield much insight on the impact of these programs, however; in fact, it has painted an even more convoluted picture of what is happening on the ground. For example, critics have condemned the large-scale displacement - of over 9000 farmers - that occurred during the first phase of operation at Newmont's Ahafo Mine in Ghana. In particular, the $\mathrm{NGO}, \mathrm{OICl}$, which was contracted by the company to identify ways to empower the displaced, has been heavily criticized for pushing people into what appears to be inappropriate alternative livelihoods, including snailrearing and soap-making. ${ }^{1}$

The company, on the other hand, has published, on its website, images of what appear to be satisfied resettled farmers, the activities taken to empower them falling under the very neutral-sounding banner 'Livelihood Restoration and Improvement Programs', now the centrepiece of the project's community development program. Toronto-based Barrick Gold is another company that has attracted significant criticism over its activities in subSaharan Africa. In particular, it has been accused of contributing very little, economically, to the communities based around its four operating mines in Tanzania North Mara, Bulyanhulu, Tulawaka and Buzwagi. Yet, the picture painted on the company's website and in its annual reports is that it is facilitating significant development in these communities by providing roads, health infrastructure, schools and economic activities. ${ }^{2}$

This paper does not seek to challenge the claims being made in the area of CSR by multinational gold mining companies operating in sub-Saharan Africa. It rather aims to raise awareness of the fragility of these pledges. Again, most CSR project work is being carried out in countries characterized by weak governance, and is being implemented directly in localities inhabited by subsistence populations that have minimal exposure to the 'wage economy' and where, at times, monitoring is low and regulations are rarely enforced. The paper focuses specifically on cases where the ownership of projects has changed. The critical question in such instances is: have the initial pledges made to community development by the original managerial staff been upheld

\footnotetext{
${ }^{1}$ See www.bicusa.org/en/Project.Concerns.23.aspx (Accessed 4 March 2010).

${ }^{2}$ See www.barrick.com/CorporateResponsibility/OurCommitment/default.aspx (Accessed 14 April 2010).
} 
by the new regime? The issue of 'inherited responsibility' or 'inherited CSR policy' has been overlooked in the extractive industries, particularly in the context of gold mining in sub-Saharan Africa.

\section{CORPORATE SOCIAL RESPONSIBILITY IN THE GOLD MINING INDUSTRY: A FLAWED DISCOURSE IN DEVELOPING COUNTRIES?}

Why would managers of large-scale gold mining companies consider prioritizing CSR at their projects in the developing world, particularly operations in subSaharan Africa? As will be explained in this section of the paper, many of the arguments tabled in support of CSR specifically, the reasons most commonly cited as explanations for why companies would view community and environmental concerns more strategically - do not apply completely to mining. The fragility of arguments on which the case for CSR in the industry is based is cause for concern, particularly in sub-Saharan Africa, where changes in ownership of projects are frequent and often unpredictable.

In exploring this issue further, the discussion that follows draws attention to points raised in Hamann's (2003) sympathetic critique of CSR in the mining sector. The author examines a number of issues in an attempt to refute Milton Friedman's claim that 'few trends could so thoroughly undermine the very foundations of our society as the acceptance by corporate officials of a social responsibility other than to make as much money for their stockholders as possible'. Many of the points which Hamann (2003) raises, however, are the very reasons why the case made for CSR in the mining sector - at least in the context of large-scale gold extraction in subSaharan Africa - is so tenuous.

\section{The business case}

Hamann (2003) contests that there is a strong business case for CSR in the mining industry - that it 'is good for profits'. For over two decades, the business case has featured at the heart of the CSR debate, popularized by industry itself. It is premised upon the idea that growing societal expectations of businesses to perform at high levels environmentally and socially require management to think more strategically about operations, and to be ever-responsive to changing consumer demands. The specific message being preached by a growing number of CEOs is that 'CSR can be a proactive business strategy and an effective marketing tool to create and sustain a competitive advantage', and that in order 'to survive and compete in the hyper-competitive global market, they (companies) must evolve from "doing good" to "doing better" and may be to "doing best" by building added societal value' (Lin et al., 2009). The business case for CSR is built upon the following hypotheses: 1 ) that it (CSR) can improve a company's image and reputation; 2) that 'cutting-edge' performance impacts positively on employee motivation, retention and recruitment; 3) that embracing it can lead to cost savings through increased efficiency and time savings due to a higher sensitivity of investors to sustainability issues; 4) that it can facilitate revenue increases through higher sales and market share; and 5) that it can reduce risks (Weber, 2008).

But to what extent do these issues apply to gold mining companies, particularly those operating in sub-Saharan Africa? Hamann (2003) argues that there is indeed a business case for CSR in the mining sector, which its senior management believes 'play(s) a crucial role in the economic and competitive strength of a mine'. The three main points the author raises in support the business case for CSR in mining, however, all centre on the role of customers, whose influence in primary sector production on the whole is minimal at best. ${ }^{3}$ The insinuation made is that in the mining sector, the link between production and consumption is linear, much like multinational firms which deliver products directly to market, such as Nike and Nestle. This, however, is far from being the case. In the latter cases, a boycott in the West against perceived 'unfair' and 'inhumane' practices at a plant in Asia, for example, could adversely impact sales in shops located along North American and European high streets, which would necessitate a radical change in corporate strategy. Conversely, such opposition in the gold mining sector, which supplies manufacturers as opposed to servicing consumers directly, would have minimal impact. The groundswell for change in the case of the extractive industries must, therefore, take place at the locations of operations themselves.

In support of the business case for CSR in mining, Hamann (2003) points out that 'customers of raw materials are becoming more and more concerned about the production conditions of the raw materials and increasingly demand certification... [and] social sustainability standards'. There is little disputing that the recent euphoria in policymaking and donor circles over issues such as climate change, renewable energy, destruction of rainforests and land degradation in developing countries has further galvanized environmentally-conscious Western consumers. In the United States, for example, surveys show that since the early 1990s, 94 percent of the population has made an effort to buy environmentallyfriendly products and that nearly 90 percent are now willing to pay more for such products (Massoud et al., 2010). One way that companies have attempted to appease such growing environmental concern is through voluntary codes and programs, which, proponents argue, can benefit a business economically if its

\footnotetext{
${ }^{3}$ The gold mining industry does not interact with everyday consumers directly. The process of producing gold comprises prospecting for ore, accessing that ore, removing and transporting economic minerals to plants for chemical and/or biological treatment, processing and refining.
} 
customers value environmental protection and are willing to pay more for the goods and services produced by businesses perceived to be environmentally friendly or to buy more of those goods and services' (Borck and Conglianese, 2009). Hamann (2003) singles out the ISO 14001 standard, the most popular certification for an environmental management system (EMS) ${ }^{4}$ and which, over the past two decades, has become the emblem of 'green' manufacturing and production. But for gold mining companies, which again, do not interact directly with consumers, what benefit would having in place an ISO 14001-certified EMS provide? The sluggish pace at which the industry has pursued certification vis-à-vis other sectors is a telling sign of the perceived utility of the standards in the industry. It is important to clarify that most mines do have an EMS in place, not to appease a concerned public but rather because it 'allows organizations to be systematic in the evaluation of their processes and activities with regard to interaction with the environment' (Massoud et al., 2010).

Another motivation behind adoption of voluntary standards such as ISO 14001 is, as Borck and Coglianese (2009) explain, that they can potentially help firms 'discover various ways to reduce their production or operating costs by using resources more efficiently or otherwise redesigning their business processes to be more environmentally benign'. In the mining sector, however, extensive planning and cost-benefit analysis takes place long before the construction of a mine can even be considered, which is why today, close to 80 percent of gold mining activity takes place in the developing world, much of it in sub-Saharan Africa (Gifford et al., 2010): since 1990, national mining legislation has been overhauled or reworked in 78 percent of the region's countries (Reichardt, 2009), a lowering of standards aimed primarily at attracting foreign investment to stimulate gold exploration and extraction. In short, the mine management of multinational gold mining companies recognize the economic advantages of operating in sub-Saharan Africa; they have a detailed budget firmly in place long before the project is opened. Assuming that the management of billion dollar investments could suddenly 'realize' additional cost savings with the implementation of voluntary codes of practice such as the ISO 14001 standards would, therefore, be overly naive.

\footnotetext{
${ }^{4}$ An EMS is the component of the overall management system that includes organizational procedures, environmental responsibilities, and processes, helps an industry comply with environmental regulations, identify technical and economic benefits, and ensures that environmental policies are adopted and followed (Barrow, 1999). It enables management to systematically 'manage' environmental impacts and facilitate improvement by helping to identify potential problems, set appropriate objectives, establish programs to achieve corporate environmental goals, and review activities to ensure that corporate environmental policy objectives are being properly carried out (Bergeron, 1997). ISO 14001 is the most recognized EMS certification worldwide; a certified EMS is one that would pass certification standards measured by an independent body.
}

The two additional points raised by Hamann (2003) in support of the business case for CSR in mining go handin-hand. First, the author contests that it is in the interest of mine management to maintain cordial relations with catchment communities in order to avoid 'local community opposition, ranging from protest to sabotage', which, it is argued 'can cause costly delays in production or even termination of production'. But whilst strained relations with local villages could certainly lead to premature mine closure, there is no evidence to suggest that a fear of community backlash would motivate management to pursue best practices during the course of operation. This is perhaps best illustrated by the case of the Niger Delta in Nigeria, where Royal Dutch Shell has had a presence since the late 1930s. The strategies used by the company to drill for oil in Ogoni land in Rivers State, where, as Frynas (1998) explains, between 1958 and 1990, it operated close to 100 wells, has, over the years, attracted criticism from even the staunchest supporters of CSR. During this period, the company, which accounts for 40 percent of Nigeria's oil production (Ite, 2007), only invested an estimated 0.000007 percent of its oil revenues into Ogoni land itself (Frynas, 1998). The Ogonis, a minority group of roughly 500,000 people, have long protested over the lack of development in the Delta, in the process, mobilizing other ethnic groups in the country that have also been adversely affected by oil production. Until only recently, Shell had managed to operate under a guise of 'responsible activity', without having any comprehensive CSR program in place: rather than finance the implementation of basic services such as electricity and piped-borne water, the company elected to invest in 'many non-functioning white elephants, including unfinished buildings designed to be health clinics or schools, water projects where the water was unfit for consumption, or projects such as health clinics which lacked light, running water, basic equipment or staff' (Frynas, 2005). Community grievances over a lack of downstream development have escalated to the point where the people of the Niger Delta are now militant, regularly sabotaging oil pipes and hijacking workers to extort monies. Towards the mid-1990s, senior management at not only Shell but at most of Nigeria's principal oil operations began to express concern over lost working days due to community disturbances. These concerns, however, proved unfounded: despite growing militancy, oil production in Nigeria actually increased toward the end of the decade.

Whilst perhaps an extreme case, the experience of Shell in the Niger Delta does nevertheless provide evidence that primary sector companies can maximize profitability without engaging in any meaningful CSR. If Hamann's (2003) argument that 'production delays are particularly problematic in the context of increasingly demanding customers in just-in-time supply chains' applied in the extractive industries in developing countries, Shell would never have been able to work in the Delta in the fashion that it has. The same applies to 
mining: what is often overlooked in analyses that link community backlash to costly disruption and/or expedited closure is how, much like Shell in the Delta, in many cases, profit has been maximized over the short and medium-term by disregarding environment and community development issues entirely. Consider, for example, the environmental disaster that occurred at the Ok Tedi Mine in Papua New Guinea (Kirsch, 2002; Banks, 2008). The mine, which up until only recently, was majority owned by BHP Billiton, commenced operation in 1984, following intensive exploration activity throughout the 1970s. Shortly after opening, however, the mine's tailings dam ruptured, which management opted not to fix. A steady stream of contaminated waste tailings contained in the pond soon began to seep into the Fly River System; discharges of toxic tailings were estimated to be in the range of $80,000 \mathrm{~m}^{3}$ daily. Ecosystems became contaminated, and the fishing grounds and agricultural lands of the 50,000 people residing in the 120 villages downstream from the project were destroyed. Following years of campaigning and lobbying, including visits made by representatives of local communities to The Hague and the US, BHP Billiton agreed to award US\$ 28.6 million in compensation in an out-of-court settlement. The company has since sold most of its shares in the mine, which is scheduled to close in 2012. The payout it has made and its potentially-expedited closure are often used to illustrate how mining companies could be adversely impacted economically if they fail to address community concerns proactively. But what often goes overlooked in the case of Ok Tedi is the amount of profits BHP Billiton managed to earn by continuing to operate without addressing the damage: in the early 1990 s, the mine was generating in excess of US\$ 50 million in profits annually.

Another illustrative example of a mine that has thrived despite mounting community opposition is Newmont's Yanacocha project in Peru, one of the Colorado-headquartered company's most profitable operations. As explained by Sarin et al. (2006), community resistance toward the project has intensified particularly in the past decade, sparked initially by a slow response to an environmental disaster on-site. In June 2000 , one of the mine's contractors spilled $150 \mathrm{~kg}$ of toxic mercury, a product of the local geology. Over 1000 people were reportedly affected, suffering from a range of healthrelated complications. Tensions have since escalated, largely over a perceived lack of local economic development: critics point to how Newmont, with support from the International Finance Corporation, has extracted US\$ 7 billion in gold at Yanacocha since starting operations in the early 1990s (Perlez et al., 2005) but that the low negotiated royalty rate of 3 percent has meant that the government has received a paltry share of these winnings, calculated to be less than US\$ 125 million in the period 2000 to 2004 (Briggs, 2005). Yet, despite

${ }^{5}$ http://www.greenleft.org.au/node/6633 (Accessed 15 April 2010). staunch community resistance over what is seen by many critics as a questionable CSR and local economic development strategy, the company has managed to maintain and occasionally increase production levels over the past decade: during the same period (2000 to 2004), a peak period of community protest, annual gold mine production nearly doubled from $1,795,398$ to $3,017,302$ oz. There are many other cases of mines operating in developing countries thriving economically in the face of mounting community opposition over low levels of economic development and/or management's disregard of environmental issues. The exhaustive list includes the Marlin Mine in Guatemala, the Kumtor gold mine in Kyrgyztan, and the Omai Mine in Guyana (EARTHWORKS, 2003; IHRC, 2007; Fulmer et al., 2008).

This leads to the second point raised by Hamann (2003), which is the idea that a mining company requires a 'social license to operate' - that companies need to 'win over' the governments of the countries where management is looking to expand, and in particular, the local populations residing within the catchment areas of activities, by demonstrating a high level of commitment to socio-economic development and environmental protection. The author argues that 'good community relations are crucial for a company's reputation, which, in turn, is vital to the company's access to financial resources, government permits and highly qualified and motivated staff'. Does the gold mining companies that have targeted sub-Saharan Africa as a destination for operation have to secure a 'social license to operate'?

\section{Securing a 'social license to operate' in Africa's gold mining sector}

It has become fashionable in recent years, particularly among scholars who argue that critics of big business overhype the influence of companies, to argue that multinational corporations need to gain the acceptance of the communities inhabiting the areas where they are proposing to operate. This has led to the coining of the phrase 'social license to operate', the idea that firms must earn a 'permit' that 'is based not on compliance with legal requirements (although, breach of these requirements may jeopardize the social license), but rather upon the degree to which a corporations and its activities are accepted by local communities, the wider society and various constituent groups' (Gunningham et al., 2002). The phrase has been heavily popularized in industry circles and, along with CSR, has been integrated into the curricula of the world's leading business schools.

Surprisingly, despite numerous claims of its validity in corporate and internet media, a 'social license to operate' has been the subject of very little empirical investigation. It is clear, however, from what little information is available, that several questionable hypotheses underpin the idea of the social license. One major assumption 
being made in the case of the gold mining sector is that the preservation of international reputation is a priority concern of senior management. The logic behind doing whatever is deemed necessary to appease catchment communities, receiving their endorsement and ultimately, securing a 'social license to operate' is that it minimizes the possibility of complications arising when attempts are made to move into other countries. One of the first companies to broach the idea was Newmont:

'In the past, a Newmont mine manager was concerned strictly with operational issues, getting the ore out of the ground. Today the manager must be able to interact with the community and generate the consent of the people in order to move the operation forward in a stable environment. For this reason, Newmont has developed what it calls "The Social License to Operate." The social license is intangible, renewable daily and granted by the people only when their needs are being met...We must constantly remind ourselves that we are guests in these countries and communities and must therefore prove ourselves on a continuing basis'. ${ }^{6}$

But if the argument applied, Newmont, which has a lengthy track record of community-level complications at not only its Yanacocha project in Peru but also in Buyat Bay, Indonesia, would never have been 'permitted' to open mines in Ghana, where even its staff has admitted it is hoping to 'get things right'. Whilst the company may indeed be doing this, the fact remains that there was no evidence at the time to suggest that it would commit to doing so. A more illustrative example is BHP Billion, whose management also emphasizes the importance of a 'social license', noting that it 'depends on the responsible operation of all aspects of our business, including our ability to work effectively with the communities in which we operate' (BHP, 2007). Again, if the argument applied, the company, whose experience at OK Tedi, claims Hamann (2003), 'has [had] direct and potentially far-reaching impacts on project and company competetiveness', would not have been able to open its Ekati diamond mine in Northern Canada with such ease.

The second assumption being made by proponents of the 'social license' is that communities are capable of holding multinational corporations - in this case, gold mining companies - accountable. In fact, the issue of community accountability resonates in the small amount of literature that has been produced on the topic to date. As Gunningham et al. (2004) explain, 'corporate executives increasingly talk about the importance of operating in accordance with their "social license," meaning that they are constrained to meet the expectations of society and avoid activities that societies (or influential elements within them) deem unacceptable'.

\footnotetext{
${ }^{6}$ www.ucdenver.edu/academics/InternationalPrograms/CIBER/GlobalForumRe ports/Documents/Newmont_Mining_Social_License.pdf (accessed 6 July 2010).
}

Proponents of the 'social license' in the gold mining sector seem to overlook the fact that landscapes are markedly different in the developed and developing worlds. In describing how the 'social license' applies to mining, Sheppard (2008) contests that a company is held in check by a range of community-level actors, including tribes, NGOs and agencies. Most of the cases cited in the literature in support of the 'social license to operate' argument, however, are from developed countries, where corporations can be held accountable. Key examples include the Brent Spar incident in the North Sea, Monstanto's failure to respond to the concerns of European consumers about the introduction of genetically modified crops, and Nike's perceived exploitation by Western consumers of labour in developing countries (Gunningham et al., 2004).

But as explained further, the political landscape is much different in sub-Saharan Africa, where transactions are made directly with governments that rarely hold corporations accountable. The argument that a gold mining company must secure a 'social license to operate' is, at least in the case of in sub-Saharan Africa, anecdotal at best.

\section{Accountability}

In addition to arguing that a business case and 'social license to operate' make CSR a necessary undertaking in the mining industry, Hamann (2003) contests that because 'companies are increasingly held to account for more indirect and cumulative impacts of their actions', there is a need for the industry to address environmental and social concerns more proactively. But who holds gold mining companies accountable in sub-Saharan Africa? More generally, who is responsible for regulating the sector in this region, where again, at times, enforcement is nonexistent?

Sub-Saharan Africa is widely considered to be the most repressive region of the world. On its latest Index of Economic Freedom world rankings of 179 countries, ${ }^{7}$ Freedom House classified eighteen of its economies as 'repressed', reporting that its 'overall level of economic freedom is weaker than that of any other region' and that 'Sub-Saharan Africa is ranked last in seven of the 10 components of economic freedom and performs especially poorly in terms of property rights and freedom from corruption,. The region's oil producers are by far its most repressive nations; most of the presidents currently in office in Cameroon, Equatorial Guinea, Gabon and Angola, rose to power in the 1970 s and 1980s. Its major

\footnotetext{
${ }^{7}$ Since 1995, The Heritage Foundation, a Washington DC-based think tank, has measured economic freedom across the world with its Index of Economic Freedom. As noted on its website (www.heritage.org), the Index covers 10 freedoms, ranging from property rights to entrepreneurship.

${ }^{8}$ 'Press Release: Sub-Saharan Africa',

http://www.heritage.org/index/pressreleases/2010/2010-Index-Sub-SaharanAfrica-Release.doc (Accessed 5 May 2010).
} 
gold producers, however, do not lag far behind. With the exceptions of South Africa and Ghana, which ranked $72^{\text {nd }}$ and $87^{\text {th }}$, respectively, on the latest Index of Economic Freedom and falling into the category of 'moderately free', all of the region's major and prospective gold producers are considered 'mostly unfree': Burkina Faso $\left(92^{\text {nd }}\right)$, Tanzania $\left(97^{\text {th }}\right)$, Mali $\left(112^{\text {th }}\right)$, Guinea $\left(134^{\text {th }}\right)$, Sierra Leone $\left(157^{\text {th }}\right)$ and Liberia $\left(163^{\text {rd }}\right)$.

In addition to being repressive, sub-Saharan Africa is widely regarded to be the most corrupt region in the world. According to transparency international's latest Corruptions Perception Index, ${ }^{9}$ 'corruption is perceived as rampant..., perceived as a serious challenge by country experts and businessmen... [and that] the overall picture remains one of serious corruption challenges across the region' (Transparency International, 2009). Perceived corruption is greatest in the region's petro-states but its gold producers are not far off: Ghana, $69^{\text {th }}$; Burkina Faso, $79^{\text {th }}$; Mali, $111^{\text {th. }}$; Tanzania, 126 $6^{\text {th }}$. Uganda, $130^{\text {th }}$; and Guinea, $160^{\text {th }}$. It appears that conditions are even worsening in countries once considered to be the region's trailblazers of 'good governance':

'High-profile anti-corruption cases and scandals continue to be regularly reported in countries including South Africa, Ghana and Senegal and risk undermining political stability as well as the governments' capacity to provide effective basic services in sectors such as education, health and water. In such a context, corruption levels can mean the difference between life and death' (Transparency International, 2009).

Many of the region's gold producers have instituted policies and programs to deal specifically with the issue of corruption, but with minimal effect. For example, in Ghana, which is often championed as a beacon of hope in sub-Saharan Africa with its recent track record of 'free and fair' elections, a 'zero tolerance policy' on corruption was implemented under the previous president, John Kufuor. The move, however, proved futile, in the end illustrating how deeply engrained corruption is in the country. A recent study commission by UNECA (2002) revealed the extent of this corruption. It pointed out how evasions, abuse and misapplication of exemption laws constitute the bane of Ghana's tax collection system. It furthermore argued that the country has weak ministerial, parliamentary and public oversight; incompetent and weak governing boards; and is characterized by excessive political interference. According to AgyemanDuah (2007), Ghana's political system, which features entrenched 'executive dominance', breeds corruption: because, in accordance with Article 78 of the constitution, the president must appoint the majority of his cabinet

\footnotetext{
${ }^{9}$ As noted on Transparency International's website (www.transparency.org), the Corruption Perceptions Index (CPI) measures the perceived level of publicsector corruption in 180 countries and territories around the world. The country with the lowest score is the one where corruption is perceived to be greatest among those included in the list.
}

from parliament, parliamentarians who are also ministers find it difficult to balance loyalties to parliament and the executive. Consequently, the author reports, potentially powerful committees such as public accounts and finance 'stay timid in their duty to scrutinize executive power, actions and assurances'.

With the governments of Ghana and the regimes of many other major gold producers in sub-Saharan Africa providing minimal support to communities and generally not using mine revenues earmarked for community development for their intended purpose, companies find themselves in positions to effectively self-regulate. Quoting Banerjee (2001), Hamann (2003) points this out, explaining that the industry's propensity to operate in remote, relatively unmonitored areas often leads to a situation where the mining company becomes a sort of de facto government'. In addition to Ghana, this appears to be the case in Mali, where 'mining codes have become increasingly economically and financially attractive, [but where] the social and environmental dimensions have followed the opposite trajectory, calling for greater responsibility by the mining companies' (Belem, 2009). To their credit, many gold mining companies have responded fairly proactively in the absence of regulation, 'bridging the gap' by instituting robust policies and programs. But their reluctance to help foster the implementation of a credible third party, such as an NGO, to regulate their activities in environments lacking government enforcement is somewhat disconcerting. The industry's solution to the cyanide management challenge at gold mines, for example, was to develop the International Cyanide Management Code, 'an industry voluntary program for gold mining companies... (that) focuses exclusively on the safe management of cyanide and cyanidation mill tailings and leach solutions'. ${ }^{10}$ Officers from the International Council on Metals and the Environment (ICME), a mining industry body, and United Nations Environmental Program helped design the code, although mining companies provided the greatest share of input. At present, 21 mining companies are signatory to the code but the initiative is not nearly as thorough as is often portrayed: it fails to include all of the activities that raise issues of security with cyanide, does not cover the environmental consequences of its usage during the design and construction of storage systems for industrial residues, and overlooks the long term effects of the closure or the rehabilitation of the mine site itself (Belem, 2009). This could explain why, despite the fanfare surrounding the code, cyanide spills continue to occur quite frequently across sub-Saharan Africa, leading many NGOs to openly question its effectiveness. ${ }^{11}$ Even some of the signatories have allegedly attempted to avoid

\footnotetext{
10 'International Cyanide Management Code: Overview' http://www.cyanidecode.org/about.php (9 May 2010).

11 'Ahafo mine cyanide spill prompts NGOs to question Intl. Cyanide Code validity'.

http://www.mineweb.com/mineweb/view/mineweb/en/page72068?oid=96302 \&sn=Detail (10 May 2010).
} 
paying fines and cleanup costs when spills have taken place. ${ }^{12}$

But it is the way in which mining companies have to come manage, institutionally, voluntary initiatives such as the International Cyanide Management Code that truly underscores how few regulatory responsibilities are exercised by African governments. In response to growing concern over the legislative implications of multinational corporations' scramble for minerals in developing countries, the ICME broadened its mandate in 2001, when it became the International Council on Mining and Metals (ICMM). Its reorganization was a direct response to recommendations made under the Global Mining Initiative (GMI), a corporate-led program aimed at identifying ways in which the mining sector could operate more sustainably (Solomon et al., 2008). It now serves as a mouthpiece for the mining sector, bringing together 19 mining companies and 30 national/regional mining and global commodity associations. The role of the ICMM has thus far failed to attract substantive discussion in the literature, although that which has been produced underscores how divergent perspectives on the issue of CSR in the mining sector are. Dashwood $(2005,2007 a$, b) is one of the biggest champions of the ICMM and the role it has played in facilitating the implementation of 'best practice' in the mining sector. Lost in all of this praise, however, is the reality of what the ICMM is: an organization established and solely financed by the sector's members, and which operates insularly. These points, discussed at some length by Sethi (2005), and Sethi and Emelianova (2006), require some clarification.

The first contentious point that Dashwood (2007b) raises relates to the ICMM enabling the mining industry to formulate sustainable development standards - that 'through the ICMM, mining companies have put forward principles of sustainable development against which mining companies can be judged' (Dashwood, 2007a). The author argues that 'the dissemination of global norms of corporate social responsibility is best conceptualized as a dynamic process, where [mining] multinationals are playing a central role, often in conjunction with NGOs and states... (and that) through these efforts, global norms have not simply filtered down, but have also been shaped by companies themselves, in an interactive or dynamic process' (Dashwood, 2007b). This decision-making process, however, is far from interactive. As Sethi (2005) explains, the way in which the ICMM and its members function is more reminiscent of 'industry-based trade associations, which are formed to protect industry members' interests in their traditional business activities'. There is no formal process to include external actors in the decision-making process and its governance

\footnotetext{
${ }^{12}$ 'EPA exposes AngloGold-Ashanti'. http://www.ghanaweb.com/GhanaHomePage/NewsArchive/artikel.php?ID=17 8270 (04 May 2010).
}

structure (Sethi and Emelianova, 2006).

This raises a second concern - namely, the social standards being championed by the industry, through the ICMM, itself. Dashwood (2005) notes that 'the ICMM has served as the institutional nucleus for coordinating a number of initiatives, including the publication of the ICMM principles in May 2003', and that 'what is significant about the ICMM's activities are the growing web of links with INGOs for the promotion of sustainable development in the mining sector'. But the aforementioned initiative attracted significant criticism from numerous NGOs, which 'accused the industry with creating an organization that is effectively controlled by the industry...- [that] the SD framework defined the issues from the perspective of the industry and offered solutions advocated by the industry' (Sethi and Emelianova, 2006). As further pointed out by Sethi (2005), the principles appear 'inspirational in character', with heavy emphasis on 'intent' and 'commitment' by member companies, therefore falling well short of 'delivering specific actions and desired outcomes'. This is significant when dealing with CSR-related issues, particularly concerns which affect communities. The ICMM has in place a mission statement on 'Mining and Indigenous Peoples', ${ }^{13}$ which states the following:

'ICMM's vision is for constructive relationships between the mining and metals industry and Indigenous Peoples which are based on respect, meaningful engagement and mutual benefit, and which have particular regard for the specific and historical situation of Indigenous Peoples. With this statement, ICMM members are making explicit a number of their commitments in this area...'

By establishing the ICMM, the mining sector has, in effect, become its own champion in the area of CSR. This is not to say that, in the absence of regulation and enforcement, the management of gold mines in subSaharan Africa is necessarily shying away from providing support to catchment communities. But demanding that constituents of the mining sector - or from any industry, for that matter - regulates and enforce themselves through a vehicle such as ICMM may not be the most effective approach. As witnessed with cyanide contamination, with weak and corrupt institutional structures that fail to hold industries accountable, the onus rests

\footnotetext{
${ }^{13}$ ICMM's Mission Statement on 'Mining and Indigenous Peoples', see http://www.indigenouspeoplesissues.com/attachments/3016_ICMM_PositionSt atement.pdf. Its six guiding principles are as follows: 1) Respect the rights and interests of Indigenous Peoples as defined within applicable national and international laws. 2) Clearly identify and fully understand the interests and perspectives of Indigenous Peoples when seeking to develop or operate mining/metals projects. 3) Engage with potentially affected Indigenous Peoples during all stages of new development projects/mining activities. 4) Seek agreement with Indigenous Peoples, based on the principle of mutual benefit, on programs to generate net benefits (social, economic, environmental and cultural) for affected indigenous communities. 5) Develop good practice guidance to support members in implementing the Position Statement. 6) Participate in national and international forums on Indigenous Peoples issues, including those dealing with the concept of free, prior and informed consent.
} 
largely on the company itself to deal with a problem, should it occur.

Here, the paper has questioned the legitimacy of the case being made in support of CSR in the gold mining industry, contesting that the main arguments underpinning it have limited application in sub-Saharan Africa. The region is rife with corruption and its governments place minimal demands on gold mining companies to be proactive in the areas of environmental protection and community development. As is highlighted further, this is potentially a major concern for communities inhabiting the catchment regions of mines that come under the management of other multinational corporations. New ownership is by no means obliged to honour the pledges made by previous management to communities. With very little to gain financially from doing so, companies often implement their own agendas, with little guidance from regulators.

\section{'INHERITED' CORPORATE SOCIAL RESPONSIBILITY AT AFRICAN GOLD MINES: AN OVERVIEW}

The thirst for foreign investment across the developing world, particularly in the extractive industries, is fuelling a 'race to the bottom'. In the face of stiff competition from other states, many developing countries have systematically 'relaxed' their environmental and social standards, as well as implemented a series of generous economic incentives, in order to attract investment and/or retain existing industries (Pegg, 2006a, b; Belem, 2009). Whilst many executives have been quick to deny that a 'race to the bottom' is, in fact, taking place, and downplay its overall influence on decisions concerning the locating of projects, the industry's current development trajectory suggests otherwise: as already noted, today, close to 80 percent of gold mining activities are found in developing countries (EARTHWORKS, 2003).

Over the past two decades, many multinational gold mining companies have established and/or expanded operations in sub-Saharan Africa in particular, lured to the likes of Ghana, Tanzania, Mali and Mozambique by a host of generous investment incentives. In Tanzania, for example, up until only recently, foreign gold mining companies were permitted to repatriate 100 percent of their profits (Lange, 2006). In Mali and Burkina Faso, a low royalty of 3 percent - a figure which has quickly become the norm across sub-Saharan Africa - is applied to production (Campbell, 2003; Forster and Bills, 2003). The amount of investment the region has attracted since the late-1980s to develop the sector has been unprecedented, as has the resulting growth in gold mining and exploration activity. Revamped mineral legislation and investment frameworks have, inter alia, stimulated a 700 percent rise in gold production in Ghana; been responsible for a doubling of gold output in Mali over the past decade; and fuelled an exploration 'boom' in Uganda, where activity is expanding by $10 \%$ annually
(Aryee, 2001; Government of Uganda, 2006; Belem, 2009). Figure 1 provides an overview of the gold mining landscape in sub-Saharan African Africa.

But it seems that as quickly as a gold mine is established in sub-Saharan Africa, it comes under the control of new ownership. Whilst takeovers and mergers are not alien to any industry, with mines, over a period of a decade, five changes in project ownership is not uncommon. As Table 2 illustrates, over the past two decades, there have been a number of rather unprecedented mergers in the gold mining industry in particular, many of which have had a profound impact in subSaharan Africa. ${ }^{14}$ New management bring new ideas and often implement radically different policies. With little evidence to suggest that CSR - at least in the conventional sense - applies to gold mining, it has become nearly impossible to forecast what a company operating in sub-Saharan Africa will do following a merger or acquisition.

The issue which this section of the paper aims to highlight is how a change in ownership can potentially convolute extant commitments to CSR and/or sideline the programs a project has in place with catchment communities. As will be illustrated using a case study of Ghana, Africa's second largest gold producer, following a number of acquisitions and mergers, a gold mine's policies on CSR and stewardship can, in fact, change - and often, quite radically. The ease with which Ghana's gold miners have been able to make major changes in areas such as community development, the environment and employment reaffirms some of the concerns raised in the previous section about the tangibility of the arguments underpinning the case for CSR in the extractive Industries, and gold mining more specifically. On a positive note, some of the more progressive gold mining companies that have acquired projects and exploration 'rights' in sub-Saharan Africa have upheld many of the commitments made by previous management, often using existing policies as a foundation to develop more comprehensive programs. But other companies have elected to ignore 'inherited' commitments completely, choosing to implement what are arguably more regressive community development programs and CSR policies. The problem in Ghana, despite being one of Africa's most democratic and peaceful countries, is that there is no real need for gold mining companies to remain committed to the pledges they 'inherit': here, governance is low, regulatory enforcement is questionable and corruption is rampant.

Regardless of location, when a company's industrial activities come under new ownership, changes are inevitable: labour forces are restructured; downsizing

\footnotetext{
${ }^{14}$ It should be pointed out that several mergers and acquisitions took place out of necessity, at a time when the price of gold had plummeted considerably. In the late 1990s and early 2000s, the price of gold hovered around US $\$ 300$, compared to its price of over US\$1000 today.
} 


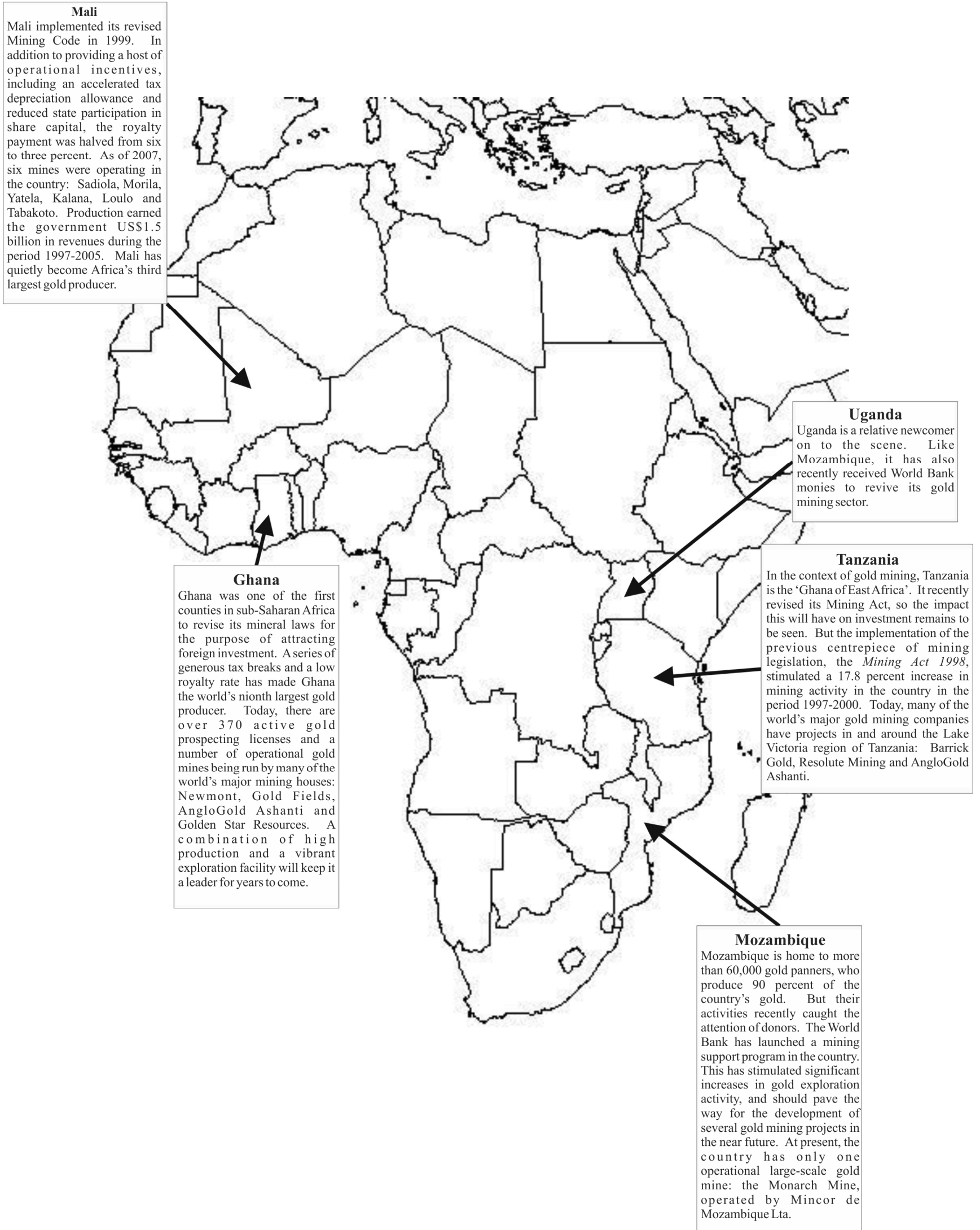

Figure 1. An overview of gold mining in sub-Saharan Africa (sources: Aryee, 2001; Government of Uganda, 2006; Carstens and Hilson, 2009; Belem, 2009). 
Table 2. Selected mergers and acquisitions in the gold mining industry, 1995 to present.

\begin{tabular}{|c|c|c|}
\hline Merger/acquisition & Year & Details \\
\hline $\begin{array}{l}\text { Barrick Gold Ltd. and Sutton } \\
\text { Resources Ltd. }\end{array}$ & 1999 & $\begin{array}{l}\text { Barrick acquired Sutton Resources for US\$ } 350 \text { million in 1999. Sutton } \\
\text { was principal owner of the Bulyanhulu project in Tanzania. }\end{array}$ \\
\hline $\begin{array}{l}\text { Barrick Gold Ltd. and Homestake } \\
\text { Mining Company }\end{array}$ & 2002 & $\begin{array}{l}\text { Barrick acquired Homestake, then one of the largest and oldest US } \\
\text { mining companies, for US } \$ 2.3 \text { billion in } 2002 \text {. }\end{array}$ \\
\hline $\begin{array}{l}\text { Barrick Gold Ltd. and Placer } \\
\text { Dome Inc. }\end{array}$ & 2006 & $\begin{array}{l}\text { Barrick acquired Placer Dome in } 2006 \text { for US\$ } 10.4 \text { billion. Among the } \\
\text { significant properties it inherited was the North Mara Mine in Tanzania. }\end{array}$ \\
\hline $\begin{array}{l}\text { Kinross Gold Corporation, TVX } \\
\text { Gold Inc. and Echo Bay Mines } \\
\text { Ltd. }\end{array}$ & 2002 & $\begin{array}{l}\text { All three companies became one corporation, Kinross Gold, in a } \\
\text { US } \$ 1.95 \text { billion merger. }\end{array}$ \\
\hline AngloGold and Ashanti Goldfields & 2004 & $\begin{array}{l}\text { AngloGold acquired Ashanti Goldfields for US\$ } 1.5 \text { billion. The new } \\
\text { company, 'AngloGold Ashanti', has major operations in Ghana, } \\
\text { Tanzania, Guinea and the DRC. }\end{array}$ \\
\hline $\begin{array}{l}\text { Newmont Gold Mining and } \\
\text { Normandy }\end{array}$ & 2002 & $\begin{array}{l}\text { Newmont acquired Australian-headquartered Normandy in } 2002 \text {. } \\
\text { Normandy was Australia's largest mining company at the time. Newmont } \\
\text { outbid AngloGold, acquiring US\$ } 4.65 \text { billion of Normandy's shares. }\end{array}$ \\
\hline $\begin{array}{l}\text { Gold Fields and Glencar } \\
\text { Resources }\end{array}$ & 2009 & $\begin{array}{l}\text { Gold Fields acquired Glencar for US } \$ 42 \text { million in } 2009 \text {. Glencar had } \\
\text { carried out significant project work in Mali, which Gold Fields is now } \\
\text { developing further. }\end{array}$ \\
\hline
\end{tabular}

often takes place; and machinery is replaced outright. These changes are made by management who, mindful of the purpose of doing business, is looking to reduce costs and maximize profits. Mergers in the mining industry almost always result in a shedding of personnel, including machine operators, drivers, and unskilled and semi-skilled labourers, many of whom are under contract. There is no convincing argument which would suggest that 'inherited' commitments to CSR, which are rarely bound by written agreement, stand a better chance of being upheld following a merger or acquisition.

This raises a more important question: if, following a takeover, a mining company does not honour the other agreements in place with the staff it has absorbed, why would its managers feel obligated to continue upholding what are no more than verbal agreements with catchment communities? Some scholars would argue for the reasons identified above - that there is a business case in doing so, a need to secure and honour a 'social license to operate', and because of accountability. But as was shown in the previous section of the paper, there is no credible foundation on which to base these arguments. The ease with which the management of so many newlyacquired gold mines has pursued an entirely different course when it has come to CSR, often in the face of stiff community resistance, illustrates, at least in the context of sub-Saharan Africa, how anecdotal these arguments are. The merging of two gold mining companies can entail the fusing of radically different corporate cultures; in cases where an acquisition has occurred outright, a new corporate strategy is often superimposed. The implications these changes have for CSR outcomes, though significant, have received minimal attention in the literature.

\section{THE CASE OF GHANA}

Perhaps the most telling indication that gold mining companies are doing very little to inform local communities about key changes to management is the continued blame placed by local people on new ownership for incidents that occurred under previous directorships. In fact, acquisitions and mergers in the sector have often occurred so quickly that even media outlets have failed to take stock of the resulting overhaul in management and corporate strategy. In Ghana, NGOs are still calling for officials at AngloGold Ashanti to be prosecuted over an incident that took place in 2003: it is alleged that guard dogs were being used to torture people caught encroaching on the company's concession in Obuasi. ${ }^{15}$ But this took place - if at all - under the leadership of then-CEO Sam Jonah, who was

\footnotetext{
${ }^{15}$ http://www.modernghana.com/news/38234/1/human-rights-abuse-localstortured-at-agc.html (Accessed 15 July 2010).
} 
relinquished of his post following AngloGold's takeover of Ashanti Goldfields in 2006. Should new management be held responsible for atrocities that took place in the past, often under a completely different regime? Part of the reason why there continues to be calls for new management of gold mines to do so in not only Ghana but throughout most of sub-Saharan Africa is that communities are simply unaware of acquisitions and mergers. For example, many residents of the Tarkwa locality continue to refer to the company operating the Damang Mine as 'AGL' (an acronym for Abosso Goldfields Limited), even though the company was acquired by Gold Fields in 2002. Residents continue to recall events that took place under the management of Abosso and request that the company honour the commitments made by its predecessor, seemingly oblivious that the mine is now under new ownership.

Walking around the Damang and Tarkwa localities of Ghana, it is not surprising that communities are unclear about issues of ownership and responsibility. There are placards, posters and signs displaying the insignias of the current operators - Gold Fields and AngloGold Ashanti of the mines in these areas, as well as remnants of past ownership, including old billboards and posters. Over the past 20 years, in addition to Gold Fields and AngloGold Ashanti, the names 'State Gold Mining Corporation', 'IAMGOLD', Ghana Australian Goldfields or 'GAG', 'Abosso Goldfields' or 'AGL', 'Pioneer', 'Ranger' and 'Teberebie' have all been linked in some way to the ownership of the Damang and Tarkwa mines - a turbulent cycle of acquisitions which even policymakers are unlikely able to recount. As Botin (2009) explains, the Damang mine, which is situated on a $50 \mathrm{~km}^{2}$ concession approximately $30 \mathrm{~km}$ from the town of Tarkwa, was originally built and operated by Ranger Minerals Limited. It was acquired by Abosso Goldfields Limited, a company which again is 100 percent owned by Gold Fields, in 2002. Today, Gold Fields retains a 71.9 percent majority share in the mine.

The changes in ownership at Damang, however, dwarf in comparison to what has unfolded at the Tarkwa mine. Botin (2009) also provides a detailed history of what has taken place in Tarkwa over the past 20 years. Today, Gold Fields Ghana, which owns 100 percent of the Tarkwa project, is 70 percent held by Gold Fields Limited $^{16}$. It acquired the Tarkwa project from the State Gold Mining Company in 1993, when it was an underground operation. It continued to function until 1999, when operations were suspended on the grounds that the project had become unviable. On 25 August 2000, however, the Ashanti Goldfields Company Limited (now AngloGold Ashanti) sold some of the assets of the adjacent Teberebie mine - including the north pit, a gyratory crusher and associated equipment - to Gold

\footnotetext{
${ }^{16}$ http://www.btimes.co.za/97/0316/comp/comp7.htm (Accessed 10 June 2010).
}

Fields for US\$ 5 million. ${ }^{17}$ Ashanti Goldfields had taken control of Teberebie through Ghana Australian Goldfields Limited, a company that it majority owned. ${ }^{18}$ Importantly, with the acquisition of these assets, Gold Fields was able to resume activities using open pit methods, which required resettling over 20,000 villagers and farmers. ${ }^{19}$

Dynamic changes in project ownership have occurred in all corners of Ghana's gold-rich territory, in many cases without informing catchment communities. As one of the busiest gold mining landscapes in sub-Saharan Africa, acquisitions of both exploration and mining rights take place all of the time, which has enormous implications for CSR and community development. In 2001, it was reported that there were 237 companies exploring for and/or mining gold in Ghana (Aryee, 2001). As of June 2010 , there were 435 active licenses, 57 of which were mining leases. Approximately 12 percent of Ghana's land is currently under concession to mining and mineral exploration companies. This includes 10 active gold mines, all of which are located in the south of the country. Most of the country's major operators have expanded their activities in Ghana through acquisitions: in addition to Gold Fields, Newmont Gold Mining, which has a project in Kenyase in the Brong-Ahafo Region, its development facilitated by its acquisition of Normandy Mining, a company that had long been engaged in exploratory work in the country; and Golden Star Resources Limited, which acquired 90 percent of Bogoso Gold Ltd. in 1999. Both Newmont and Golden Star Resources have since established extremely profitable projects but on the back of very different CSR and community development agendas to those 'inherited'. The following analysis reinforces concerns raised earlier in this paper: in Ghana, the ease with which gold mining companies have had with implementing their own CSR policies suggests that there is minimal pressure to implement comprehensive programs and be proactive, let alone honour commitments made by previous management to community development and environmental protection.

In 2002, Newmont Mining Corporation acquired Normandy Mining, an Australian-headquartered company which, at the time of takeover, had carried out considerable exploratory work in Ghana. At the time, Normandy's CSR program was in an embryonic state, something which Newmont sought to change. As was briefly explained in the previous section of the paper, Newmont has used Ghana as a platform for a 'new beginning' in the area of CSR. During the build-up to the muchanticipated opening of its Ahafo project, Newmont management worked exhaustively to sensitize communities on the ground and empower subsistence groups

\footnotetext{
${ }^{17} \mathrm{http} / / / \mathrm{www} . \mathrm{modernghana.com} /$ news/9952/1/ashanti-completes-sale-ofteberebie-assets-to-gold.html (Accessed 15 June 2010).

${ }^{18} \mathrm{http}: / /$ www.ifc.org/ifcext/spiwebsite1.nsf/projects/B36A911EB57333648525 76C10080CC2E (Accessed 29 June 2010).

${ }^{19}$ http://www.btimes.co.za/97/0316/comp/comp7.htm (Accessed 17 June 2010).
} 
destined to be displaced. As explained at the time by Mawuena Dumor, the-then communications manager of Newmont Ghana:

'This is in order to ensure that we do not encounter problems that other mining companies have encountered when we do start pouring gold in 2006...We [Newmont] are currently holding stakeholder consultations with the communities, their chiefs and elders and the people themselves and finding ways of providing them with sustainable alternative livelihoods'. ${ }^{20}$

Why has Newmont elected to implement such a comprehensive CSR project at its Ahafo project? Management has cited similar reasons to those highlighted in this paper, including that there is a business case for doing so and the need for a social license to operate - messages which are found throughout the Newmont website.

The view here, however, is that the decision by Newmont to implement a fairly comprehensive CSR agenda is less about there being a need to do so and more to do with an unfamiliarity with the dynamics of doing business in sub-Saharan Africa. Being its first significant project in the region, it appears that management has elected to take a more cautious approach to environmental and social issues than those pursued at the company's projects in Peru and Indonesia. In many ways, Newmont has been its own champion, using various media outlets to publicize its intentions on being a good citizen and starting fresh in Ghana. The Ahafo mine, which at the time of its opening, had close to 12 million oz of proven gold reserves, processes ore from seven major pits (four in the south and three in the north) that extend along a $40 \mathrm{~km}$ strike. Its rate of production is in the range of $500,000 \mathrm{oz}$ of gold/year (Mitchell and Jorgensen, 2007). This, however, was only made possible by a comprehensive relocation exercise, which involved the resettlement of close to 10,000 farmers and their families. Few resettlements go according to plan, but to their credit, Newmont officials agreed to award compensation packages based on sums much higher than the highly-outdated figures used by the government. Working with a local NGO, 'Guards of the Earth and the Vulnerable', a Resettlement Negotiation Committee composed of democratically-elected facilitators was formed. The resulting negotiations spearheaded by the NGO yielded a compensation agreement amounting to 103 percent more than the original figure. ${ }^{21} \mathrm{~A}$ commitment to its program would help the company achieve record levels of production $(513,470 \mathrm{oz}$ of gold) at Ahafo in $2009 .^{22}$

\footnotetext{
${ }^{20} \mathrm{http}: / /$ www.ghanaweb.com/GhanaHomePage/NewsArchive/artikel.php?ID=6 1568 (Accessed 5 July 2010).

${ }^{21} \mathrm{http} / / /$ gevghana.org/mission.pdf (Accessed 6 July 2010). http://modrnghanaweb.com/34480xn/ghana-s-gold-production-up-12-in2009.htm (Accessed 7 July 2010).
}

Newmont has since been fairly responsive to other issues as well. For example, in April 2010, the company agreed to pay close to US\$ 4.8 million to cover damages caused by a cyanide ${ }^{23}$ spill at the Ahafo Mine in October 2009. ${ }^{24}$ Whilst Newmont should be held responsible for these costs, its decision to dispense of these monies rather quickly was nevertheless significant, given the way, historically, mining companies have responded to cyanide spillage: there is a long list of companies operating in developing countries that have successfully manoeuvred their way out of paying for cleanup following an accident. Another rather commendable move was the company's decision to dismiss its Head of Security at Ahafo in 2007, after he allegedly referred to some of his workers as 'black monkeys'. This caused significant agitation in Ahafo's communities, leading the chiefs and youth to demonstrate and call for his removal. Newmont officials, which had spent several years building positive relations with the residents of Ahafo's catchment communities, particularly their traditional leaders, had no choice but to sack and summarily deport its head of security. ${ }^{25}$

But Newmont's effort could be viewed differently: as a CSR program that appears to be comprehensive but which, in reality, the public knows very little about. The company has been cleverly using the media since its takeover of Normandy to project a positive image about its intentions and CSR strategy in the public domain. It uses the Ghana's Daily Graphic, Ghanaian Times and Accra Daily, Ghana's main state-owned newspapers to keep the public abreast of CSR at Ahafo, although the effort has increasingly become more propaganda-like. Moreover, it has established a website, 'Beyond the mine: The journey towards sustainability', on which its management details what it views as concrete examples of 'best practice' at its mines worldwide, including experiences from Ahafo.

The concern here is not necessarily with what Newmont officials have created but rather the autonomy they have been given to develop polices: its CSR program may, indeed, be robust but it was developed without much outside guidance and its impact, as will be explained, is virtually unverifiable. Management has solicited the inputs of NGOs such as Guards of the Earth and the Vulnerable and $\mathrm{OICl}$ to assist with the design of its CSR program at Ahafo but why has the government not provided any additional guidance on this front? Unlike many other gold mining territories in sub-Saharan Africa, in the Ahafo locality, there was no legacy of CSR. Newmont simply formulated a program, drawing heavily upon wider ICMM principles and staff expertise, to implement what appears to be an extremely complex

\footnotetext{
${ }^{23}$ Cyanide is the leach reagent used to process gold. Although it degrades relatively rapidly in the natural environment, it can be toxic in trace quantities. ${ }^{24}$ http://www.ghanaweb.com/GhanaHomePage/NewsArchive/artikel.php?ID=1 80236 (Accessed 4 June 2010)

25 http://www.modernghana.com/news/144920/1/ghana-chamber-of-minescondones-racism-wacam.html (Accessed 4 April 2010).
} 
community relations management structure. When it came time for resettling farmers or when cyanide was spilled, criticisms from local NGOs such as the Wassa West Association of Communities Affected by Mining (WACAM) were seen by the public as baseless and complaints from the community heavily suppressed, in large part because of the success of the company in projecting itself, through the media, as a responsible citizen.

Attempts made to monitor what has become a very fortified CSR program at Ahafo, unaffected by criticism, have been in vain. One of the most unexplained events was the arrest of OXFAM International's West Africa Program Officer at Yamfo. On 30 November 2006, Mr Ibrahima Aidiara and six others were apprehended by local police, the Brong Ahafo Regional Police Commander alleging that they planned to incite the people in the town to revolt against Newmont gold mining operations there,. ${ }^{26}$ It was further explained that the seven, who remained in detention until 11 December $2006,{ }^{27}$ were arrested on the grounds that they had not informed the police of the event beforehand. Although company officials denied any knowledge of the incident, it does raise the question of why the police would act in such a manner unless under specific instruction to do so. In response to the arrest, Newmont declared that it:

'...expresses concern and confusion regarding these developments. The company is continuing its commitment to understand the circumstances which have resulted in this outcome. Newmont only last week (Friday November 24, 2006) participated in a meeting with members of WACAM and OXFAM in Accra at their request and to the company's mutual satisfaction. Newmont, WACAM and OXFAM agreed to meet at the Newmont mine site at Ahafo today (November 28) to further discuss issues of mutual interest and concern. It is regrettable that WACAM and OXFAM decided to boycott the scheduled meeting of November 28 following the incident at Yamfo, ${ }^{28}$

Despite claiming otherwise, it is rather unlikely that Newmont officials had little knowledge of the arrest or any other event for that matter that takes place on a concession housing billions of dollars in investment. The company's rather ambiguous response has done little to quell accusations made by NGOs that its management is bribing police. ${ }^{29}$ Of particular concern is the lack of government response to the incident; there have been no

\footnotetext{
${ }^{26}$ http://www.modernghana.com/newsp/120769/1/pagenum1/wacamimplicates-newmont-in-arrest-of-activists.html\#continue (Accessed 13 April 2010).

${ }^{27}$ http://mobile.ghanaweb.com/wap/article.php?ID=114803 (July 13 2010).

${ }^{28} \mathrm{http}$ ://www.reports-and-materials.org/Newmont-Ghana-Yamfo-incidentrelease-28-Nov-2006.doc (Accessed 15 June 2010).

${ }^{29}$ It has been alleged that Newmont has provided funding for a new police station in Birim North District, where it has opened a second mine, Akyem. See http://www.fian.org/news/resources/documents/others/mining-related-humanrights-violations-ghana/pdf (Accessed 10 May 2010).
}

calls for Newmont to have its community development program thoroughly subjected to monitoring by outside sources. This further reinforces the concerns raised earlier in this paper regarding the lack of monitoring and regulatory inputs in African settings.

Whilst the event looks rather suspicious, a likely reason behind Newmont shielding such 'uncontrolled' inspections and visits is its need to appease the International Finance Corporation (IFC), which has provided significant financial assistance for the project. The IFC, which is faced with pressures of its own, the most significant being those emanating from a consortium of neighbouring Washington DC-based NGOs, has responded to outside criticisms of its investments by demanding that borrowers like Newmont ensure that their projects adhere to certain environmental and social standards. Perhaps allowing outside inspection could have run the risk of revealing potentially damaging findings. In sum, despite not inheriting any legacy from Normandy, Newmont Ghana has managed to decide, relatively autonomously, what development trajectory it will follow. It continues to operate a rather insular CSR program which may or may not be making a difference. Its approach has proved effective under the circumstances, however, netting the company record levels of production and profits.

Golden Star Resources, on the other hand, has not been anywhere near as proactive as Newmont on the CSR front but has nevertheless achieved similar success economically. Unlike Newmont, the Denver-based company did move into an area where there was a legacy of CSR and firm commitments in place with the community. As already explained, its move to Ghana was facilitated by its acquisition of a 90 percent share in Bogoso Gold Ltd. (BGL) in 2004 (Hilson and Yakovleva, 2007). Golden Star Resources owns the $145 \mathrm{~km}^{2}$ Bogoso concession and the surface rights to the adjoining 129 $\mathrm{km}^{2}$ Prestea concession. The acquisition of Prestea was facilitated by a joint venture made in 2002 between BGL, the-then State Gold Mining Company, the Ghana Mine Workers Union and Prestea Gold Resources. The latter was assembled by former employees of the State Gold Mining Company, in 1998. It was a last-ditch attempt to save the floundering underground workings in Prestea but which, after incurring in excess of US\$ 6 million in losses over the period 1999-2001, management was forced to close. As part of the agreement made in 2002, BGL management committed to providing US\$2.4 million to cover the salaries and debts owed by Prestea Gold Resources, as well as to assess the feasibility of the underground project.

As noted, in BGL, Golden Star Resources took over a company whose management had forged good relations with the community. It supplied the residents of Prestea with electricity and water free of charge. It even signed a contract with former employees of Prestea Gold Resources, 'permitting' them to mine artisanal workings at the 'Number Four Bungalow' site on the Prestea 
concession - a move made to help alleviate the hardship created by the closure of underground activities. Relations were so cordial that the Prestea community renamed the town's park to 'Neil Stevenson Park' as a token of appreciation to the-then BGL manager for all of his efforts.

All of this changed, however, following the takeover. With no requirement or expectation on the part of the government to build upon the foundation of CSR established by its predecessor, new management elected not to honour any of the commitments already in place, and did so without penalty. Some would say that it proved to be a public relations nightmare but this approach has never adversely impacted the profitability of Golden Star Resources, nor did it impede its entry to Ghana: the government seemed to welcome the company despite its questionable track record, highlighted by its refusal to compensate local residents following a cyanide spill at the Omai Gold Mine (in which it held a 30 percent stake) in Guyana. Its management contested at the time that such accidents 'are one of the many risks of doing business' (Garvey and Newell, 2005). It seemed that from the beginning, management had no qualms about alienating the Prestea and Bogoso communities.

First, management stopped financing electricity and water service for residents, and called in the military to remove miners from the 'Number Four Bungalow' site, despite having very little interest in mining the area. A decision was then made to carry out blasting without notifying communities (Ghana had no noise pollution standards at the time), which residents claimed caused damages to their houses and structures. There was also an incident in the town of Dumasi, where water used for cooking was turning purple because of contamination from mine drainage. The company now transports large canisters of drinking water to the town every week. Local NGOs have encouraged communities to protest against the company and the government. The 'Concerned Citizens of Prestea' was formed shortly after the takeover but every peaceful protest it has since organized has resulted in shootings or casualties. ${ }^{30}$ The company even hired Newmont's former Director of Security, who again, was deported from the country by Newmont following the incident at Ahafo, as its own Head of Security, prompting further outcry from local NGOs. ${ }^{31}$ But complaints of Golden Star Resources and its rather unique approach to community development have not prevented it from mining profitably: the company projected gold production to be in the range of $200,000 \mathrm{oz}$ in 2010 . Moreover, the radical departure in approach from the pre-existing CSR program of $B G L$ and the mounting grievances it has brought has not prevented the company from acquiring contiguous concessions in Wassa Akropong, another

\footnotetext{
${ }^{30} \mathrm{http}$ //www.modernghana.com/news/80088/1/seven-injured-in-ademonstration-at-prestea.html (Accessed 12 July 2010).

${ }^{31}$ http://www.modernghana.com/news2/144920/1/ghana-chamber-of-minescondones-racism-wacam.html (Accessed 15 April 2010).
}

(adjacent) district in Ghana.

To summarize, Newmont and Golden Star Resources have approached their situations rather differently. This analysis does not advocate either as a 'best practice'. It has rather sought to underscore how a wide range of approaches to CSR can be taken in Ghana's gold mining sector. These case studies bring to light some of the concerns raised earlier in the paper over issues on which proponents of CSR engaged in not only gold mining in developing countries but the extractive industries more generally base their arguments. Newmont and Golden Star Resources have been able to implement radically different CSR programs to those of the companies they acquired because there is minimal pressure to implement comprehensive environmental protection and community development programs, and, perhaps most importantly, to honour the pledges made by the management of projects acquired. Gold mining companies with poor environmental and community development track records have been able to readily establish themselves in Ghana and a number of other countries in sub-Saharan Africa. With no evidence to suggest that being proactive on the CSR front in the industry results in financial gain, it has become almost impossible - at least in the case of subSaharan Africa - to predict which path a gold mine will follow.

\section{CONCLUDING REMARKS}

This paper has drawn attention to the issue of 'inherited CSR' in the context of the extractive industries, focusing specifically on the case of gold mining in sub-Saharan Africa. Throughout the region, it has become exceedingly difficult to predict how new ownership will approach the interrelated challenges of environmental protection and community development following a takeover of a gold mine. The arrival of new management results in a fusion of corporate cultures, which, in turn, can lead to the setting of - often radically - different goals and the implementation of new programs. Surprisingly, little research has been undertaken to determine the impact a merger or outright takeover of a company has on CSR strategy at a mine, including the fate of commitments made by previous management. New management no doubt handles these pledges much in the same way that it would issues such as staffing and operations. The key difference and concern with CSR, however, is that unlike staff or suppliers, who are often under contract, commitments to community development and often, environmental protection, are rarely much more than verbal or written promises.

Though virtually overlooked in the literature, the issue of 'inherited CSR' in the gold mining industry is signifycant, particularly for sub-Saharan Africa. As explained in this paper, the region is characterized by low transparency and rampant corruption; many of its countries are run by governments that have systematically 
marginalized populations to stay in power. Is a company that is due to operate in such an environment expected to honour the agreements forged by its predecessor following the takeover of a gold mining project? Proponents argue that for gold mining companies, a firm commitment to CSR is necessary in order to maximize profits. But as the analysis presented earlier in this paper shows, the arguments commonly tabled in support of CSR in the gold mining sector are tenuous, particularly in the case of sub-Saharan Africa. Understanding the limitations of these views helps to explain why, following a change in ownership of a gold mine, commitments to CSR are often sidelined and/or overhauled completely. As was illustrated by the Ghana experience, there does not appear to be much pressure on incoming companies to honour existing commitments to communities and/or the environment, or to even implement CSR programs of their own. In fact, and as illustrated by the case studies of Newmont and Golden Star Resources, in the absence of rules and regulations, new management is at liberty to implement policies and programs of their choice.

The main concern in the case of sub-Saharan Africa is that despite the rhetoric, there is no convincing evidence to suggest that having in place comprehensive environmental policies and protection strategies, as well as cutting-edge community development programs, increases the profitability of a gold mine. This could explain why, for instance, the local economic development exercises launched in the catchment areas of mines often lose their cohesion so quickly, or why cyanide management systems become less effective over time: the ownership of a project changes quite frequently, and following each handover, aspects of the operation is evaluated, re-evaluated and potentially changed. In such an economic climate, it would be unrealistic to assume that a mine's stakeholders are seen by management as being equal. This is an issue discussed quite extensively by Argenti (1998), who acknowledges that 'companies perform better the more closely they engage everyone affected by their operations' but at the same time, recognizes that 'an organization designed to serve more than one set of people will fail to satisfy any'. A main message which the author attempts to get across is that every company values key stakeholder groups differently, depending on the circumstances. The key question, therefore, becomes: what must a company do in order to guarantee a maximum return to its shareholders? In the case of gold mines in sub-Saharan Africa, there is no reason to believe that communities are anywhere near as integral to the financial success of a project as portrayed by business leaders. This possibility, along with the frequent changes in ownership of the region's gold mines and the marked variations in corporate strategies found across the industry, makes an improved understanding of how incoming management handles outstanding commitments to communities and the environment, as well as how it develops CSR programs of its own, imperative.

\section{REFERENCES}

Agyeman-Duah B (2007). Curbing Corruption and Improving Economic Governance: The Case of Ghana. Ghana Centre for Democratic Development, Accra.

Argenti J (1997) Stakeholders: the Case Against. Long Range Plan., 30(3): 442-445.

Aryee BAA (2001) Ghana's mining sector: its contribution to the national economy. Resources Policy., 27(2): 61-75.

Banerjee SB (2001) Corporate citizenship and indigenous stakeholders: exploring a new dynamic of organisationalstakeholder relationships. J. Corp. Citizen., 1(1): 39-55.

Banks G (2008) Understanding 'resource' conflicts in Papua New Guinea. Asia Pac. View., 49(1): 23-34.

Barrow CJ (1999) Environmental Management: Principles and Practice. London: Routledge, Taylor \& Francis Group.

Belem G (2009) Mining, Poverty Reduction, The Protection of the Environment and the Role of the World Bank Group in Mali, pp 119-149, in Mining in Africa: Regulation and Development (ed. B. Campbell). London: Zed Books.

Bergeron P (1997) The ISO 14000 series of environmental management standards. in OECD Proceedings 'Cleaner Production and Waste Minimisation in OECD and Dynamic NonMember Economies',pp. 253-261, Paris: OECD.

Botin JA (2009) Integrating Sustainability into the Organization, pp. $71-133$, in Sustainable Management of Mining Operations (ed. J.A.Botin), Colorado: Society for Mining, Metallurgy and Exploration.

Bowman EH, Haire M (1975) Strategic posture towards Corporate Social Responsibility. Calif. Man.Rev., 18(2): 49-58.

Borck JC, Conglianese C (2009) Voluntary environmental assessment programs: Assessing their effectiveness. Ann. Rev. Env. Res., 34: 305-324.

Briggs D (2005) Yanacocha Complex Report. Mining Operations Report. Denver: Newmont.

Byron W (1982) In Defense of Social Responsibility. J. Econ. Bus., 34: 189-192.

Campbell B (2003) Factoring in governance is not enough. Mining codes in Africa: Policy reform and corporate Responsibility. Minerals Energy., 18(3): 2-13.

Carroll AB (1975) Corporate Social Responsibility - Its Managerial Impact and Implications. J. Bus. Res., 2(1): 75-88.

Carroll AB (1978) Setting operational goals for Corporate Social Responsibility. Long Range Plan., 11(2): 35-38.

Carstens J, Hilson G (2009) Mining, grievance and conflict in rural Tanzania. Int. Dev. Plan. Rev., 31(3): 302-326.

Chen JC, Patten DM, Roberts RW (2008) Corporate charitable contributions: A corporate social performance or legitimacy strategy? J. Bus. Ethics., 82(1): 131-144.

Dashwood HD (2005) Canadian Mining Companies and the Shaping of Global Norms of Corporate Social Responsibility. Int. J., 60(4) 977-998.

Dashwood HD (2007a) Towards Sustainable Mining: The Corporate Role in the Construction of Global Standards. Multi. Bus. Rev.,15(1): 47-65.

Dashwood HD (2007b) Canadian Mining Companies and Corporate Social Responsibility: Weighing the Impact of Global Norms. Can. J. Pol. Sci., 40(1): 129-156.

Dunlap RE, Mertig AG (1991) The Evolution of the United States Environmental Movement from 1970 to 1990 - An Overview. Soc. \& Nat. Res., 4(3): 209-218.

EARTHWORKS (2003) Dirty Metals: Mining, Communities and the Environment. Washington DC: EARTHWORKS.

Forster JJ, Bills JH (2002) Comparison of the impact of the fiscal regime on gold projects in Tanzania and Burkina Faso. Tran. Inst. Min. Met., 111: 195-199. (CITED AS Forster AND Bills, 2003)

Frynas JG (1998) Political instability and business: Focus on Shell in Nigeria. Third World Quart., 19(3): 457-478.

Frynas JG (2005) The false developmental promise of Corporate Social Responsibility: Evidence from multinational oil companies. Int. Aff., 81(3): 581-598.

Fulmer AM, Gudoy AS, Neff P (2008) Indigenous Rights, Resistance 
and the Law: Lessons from a Guatemalan Mine. Lat. Am. Pol. Soc., 50(4): 91-121.

Garvey N, Newell P (2005) Corporate accountability to the poor? Assessing the effectiveness of community-based strategies. Develop. Prac., 15(3-4): 389-404.

Gifford B, Kestler A, Anand S (2010) Building local legitimacy into corporate social responsibility: Gold mining firms in developing nations. J. World Bus., 45(3): 304-311.

Government of Uganda (2006) Investing in Uganda's Mineral Sector. Government of Uganda, Kampala. http://www.ugandainvest.com/mining.pdf (Accessed 28 July 2010).

Gunningham N, Kagan RA, Thornton D (2002) Social License and Environmental Protection: Why Businesses go Beyond Compliance. Berkeley: Center for the Study of Law and Society, University of California Berkeley.

Gunningham NA, Thornton D, Kagan RA 2005. Motivating management: Corporate compliance in environmental protection. Law Pol., 27(2): 289-316.

Hamann R (2003) Mining companies' role in sustainable development: The 'why' and 'how' of corporate social responsibility from a business perspective. Dev. South. Afr., 20(2): 237-254.

Hilson G, Yakovelva N (2007) Strained relations: a critical analysis of the mining conflict in Prestea, Ghana. Pol. Geog., 26(1): 98-119.

Holmes SL (1976) Executive Perceptions of Corporate SocialResponsibility. Bus. Hor., 19(3): 34-40.

International Human Rights Clinic (IHRC) (2007) All That Glitters: Gold Mining in Guyana. Cambridge: Human Rights Program, Harvard Law School.

Ite UE (2007) Partnering with the state for sustainable development: Shell's experience in the Niger Delta, Nigeria. Sus. Dev., 15(4): 216-228.

Jenkins H, Yakovleva N (2006) Corporate social responsibility in the mining industry: Exploring trends in social and environmental disclosure. J. Clean. Prod., 14(3-4): 271-284.

Kapelus $P$ (2002) Mining, corporate social responsibility and the "community": The case of Rio Tinto, Richards Bay minerals and the Mbonambi. J. Bus. Ethics., 39(3): 275-296.

Kirsch S (2002) Anthropology and advocacy - A case study of the campaign against the Ok Tedi mine. Crit. Anthro., 22(2): 175-200.

Lange S (2006) Benefit Streams from Mining in Tanzania: Case Studies from Geita and Mererani. CMI Report 2006:11. Bergen: Chr. Michelsen Institute.

Lin $\mathrm{CH}$, Yang HL, Liou DY (2009) The impact of corporate social responsibility on financial performance: Evidence from business in Taiwan. Tech. in Soc., 31(1): 56-63.

Logsdon LM (1996) How corporate social responsibility pays off. Long Range Plan., 29(4): 495-502.

Massoud MA, Fayad R, Kamleh R, El-Fadel M (2010) Environmental Management System (ISO 14001) Certification in Developing Countries: Challenges and Implementation Strategies. Env. Sci. Tech., 44: 1884-1887.

Mitchell J, Jorgensen MK (2007) Newmont's Ahafo Mine - gold mining in West Africa. Mining Engineer., 59(4): 23-28.

O'Faircheallaigh C (2006) Aborigines, mining companies and the state in contemporary Australia: a new political economy or 'business as usual'? Aust. J. Pol. Sci., 41(1): 1-22.

O'Faircheallaigh C (2010) Aboriginal-Mining Company Contractual Agreements in Australia and Canada: Implications for Political Autonomy and Community Development. Can. J. Dev. Stud., 30(1-2): 69-86.

Ostlund LE (1977) Attitudes of managers toward Corporate Social Responsibility. Cal. Man. Rev., 19(4): 35-49.
Pegg S (2003) Poverty Reduction or Poverty Exacerbation? World Bank Group Support for Extractive Industries in Africa. Oxfam America: Washington DC.

Pegg S (2006) Mining and poverty reduction: Transforming rhetoric into reality. J. Clean. Prod., 14(3-4), pp. 376-387.

Perlez J, Bergman L, Telvick M, del Toro N (2005) Treasure of Yanacocha: Tangled in Fight over Peru Gold Mine. New York Times 25 October.

Reichardt CL (2009) The challenge of building capacity to support the development of a sustainable mining industry in emerging mining nations. J. South Afri. Inst. Min. Met., 109(3): 163-168.

Sarin R, Reisch N, Kalafut J, Slack K (2006) Tarnished Gold: Mining and the Unmet Promise of Development. Washington DC: EARTHWORKS.

Sethi SP (2005) The effectiveness of industry-based codes serving public interest: the case of the International Council on Mining and Metals. Trans. Corp., 14(3): 55-99.

Sethi SP, Emelianova O (2006) A failed strategy of using voluntary codes of conduct by the global mining industry. Corp. Gov., 6(3): 226-238.

Shanklin WL (1976) Corporate Social-Responsibility - Another View. J. Bus. Res., 4(1): 75-84.

Sheppard RB (2008) Gaining a social license to mine. Min. Mag., April: 20-23.

Solomon F, Katz E, Lovel R (2008) Social dimensions of mining: Research, policy and practice challenges for the minerals industry in Australia. Resources Policy., 33(3): 142-149.

Transparency International (2009) Corruption Perceptions Index 2009 - Regional Highlights: sub-Saharan Africa. London: Transparency International.

United Nations Economic Commission for Africa (UNECA) (2002) Monitoring Progress Towards Good Governance: National Country Report - Ghana. Undertaken by the Ghana Centre for Democratic Development, Accra.

Warhurst A (2001) Corporate Citizenship and Corporate Social Investment: Drivers of Tri-Sector Partnerships. J. Corp. Citizen., 1: 57-73.

Weber M (2008) The business case for corporate social responsibility: A company-level measurement approach for CSR. Euro. Man. Rev., 26(4): 247-261.

Weitzner V (2010) Indigenous participation in multipartite dialogues on extractives: What lessons can Canada and others share? Can. J. Dev. Stud., 30(1-2): 87-109.

World Bank (1992) A Strategy for African Mining. Washington DC: World Bank.

Young EA (1992) Aboriginal land rights in Australia - Expectations, achievements and implications. App. Geog., 12(2): 146-161. 